www.jmscr.igmpublication.org

Index Copernicus Value: 79.54

ISSN (e)-2347-176x ISSN (p) 2455-0450

crossref DOI: https://dx.doi.org/10.18535/jmscr/v7i6.36

\title{
Assessment of Nutritional Status among Adolescents in an Urban Field Practice Area of a Medical College in West Bengal, India
}

\author{
Authors \\ Dr Avijit Paul ${ }^{1}$, Dr Soma Chakrabarti2*, Dr Shuvankar Mukherjee ${ }^{3}$, \\ Prof. Dr Nabanita Bhattacharyya ${ }^{4}$
}

${ }^{1}$ MBBS, MD (Community Medicine), Assistant Professor, Department of Community Medicine, Calcutta National Medical College, Kolkata

${ }^{2}$ MBBS, DPH, MD(Community Medicine), Assistant Professor, Department of Community Medicine,

Calcutta National Medical College, Kolkata

${ }^{3}$ MBBS, DPH, MD (Community Medicine), Assistant Professor, Department of Community Medicine, Calcutta National Medical College, Kolkata

${ }^{4}$ MBBS, MD (Community Medicine), Professor and HOD, Department of Community Medicine, Calcutta

National Medical College, Kolkata

*Corresponding Author

Dr Soma Chakrabarti

E - 1/ 5, Saltee Spacio, 1, Mall Road, Kolkata - 700080, India

\begin{abstract}
Good nutrition and appropriate lifestyle behavior are essential for optimum growth and development of adolescents. Since malnutrition during adolescence affects the future of not only the individuals but the society as a whole, so this present study was carried out among adolescents in slums with the aim of asessng their nutritional status and to find out the sociodemographic factors influencing malnutrition among them. A cross-sectional, descriptive, observational study was carried out in three randomly selected slums in the urban field practice area of Calcutta National Medical College. A sample of 291 adolescents were selected following complete enumeration technique among the permanent residents of those slums. A predesigned, pretested, structured schedule was used for collecting data regarding nutritional status and sociodemographic factors. The study population was found to be comprised of $123(42.3 \%)$ males and 168 (57.7\%) females. According to BMI, among the study population 21 (7.2\%) were obese, 30 (10.3) were over-weight, 135 (46.4\%) were normal, 90 (30.9\%) were thin and 15 (5.2\%) were very thin. Gender, religion, education of parents, type of family and socio-economic status were found significantly associated $(p<0.05)$ with different categories of BMI. Thus strengthening adolescent health through adolescent health clinics will ameliorate their nutritional and other health related problems.

Keywords: Adolescents, Nutritional status, BMI for age, urban.
\end{abstract}

\section{Introduction}

The term adolescence is derived from the Latin word "adolescere" meaning "to grow up", the
World Health Organization (WHO) defines adolescents as individuals aged 10-19 years. ${ }^{(1)}$ Adolescence is often divided into early (10-13 
years), middle (14-16 years) and late (17-19 years) adolescence. $^{(2)}$ There are around 350 million adolescents comprising about $22 \%$ of the population in countries of the South-East Asia Region (SEAR). ${ }^{(3)}$ The adolescence is defined as the period of transition between childhood and adulthood and is characterized by an exceptionally rapid rate of growth. ${ }^{(4)}$ It is one of the most rapid and formative phases of human development.

Adolescence is a window of opportunity not only for a healthy and productive adulthood but also a period of risk as health problems can have serious consequences immediately or later in life. It is the time when the nutrient requirements of the body are high. Inadequate nutrition in adolescence can potentially retard growth and sexual maturation, and can put them at high risk of chronic diseases particularly if combined with other adverse lifestyle behaviours.

According to 2011 census of India, 20.9\% of total population is adolescents, and in West Bengal they comprise $7.2 \%$ of total population. ${ }^{(5,6)}$

The prevalence of malnutrition is a major public health concern in most of the developing countries in Asia. India, with its vast size, socioeconomic disparities, illiteracy etc. is not an exception to it. So, a large number of adolescents suffer from chronic malnutrition which adversely impacts their health and development. Addressing the nutritional needs of adolescents could be an important step towards breaking the vicious cycle of intergenerational malnutrition, chronic diseases and poverty. Hence, assessment of nutritional status, particularly among adolescents, plays a very crucial role in formulating future developmental strategies for the country.

Though a lot of national health programmes have been implemented to combat the menace of malnutrition among adolescents, yet till date the problem still persists. Also, most of the studies on adolescent nutrition had been conducted in the rural setup. Since data in urban setup is very hard to come by, not only in India but also in West Bengal, this study was carried out among the adolescents with the following objectives:
1) To assess the nutritional status of the adolescents residing in the selected slums of the urban field practice area of Calcutta National Medical College, Kolkata.

2) To find out the association, if any, between socio-demographic profile and nutritional status of the study population.

\section{Materials \& Methods}

Type of study: Descriptive observational study

Study design: Cross sectional

Place of study: Urban field practice area of Calcutta National Medical College (CNMC), Kolkata

Study duration: 6 months

Study population: Adolescents who were permanent residents of the area

\section{Exclusion Criteria}

i. Seriously ill adolescents

ii. Adolescents who had not given informed consent

iii. Adolescents with any congenital disorder.

Sample size: Total sample size consisted of 291 adolescents.

Sampling Technique: 3 slums were randomly selected in the field practice area. All the adolescents who were permanent residents of these slums and outside the exclusion criteria, had been included in the study following complete enumeration technique.

\section{Study Technique}

- Interview method.

- Clinical Examination - height, weight, BMI, waist - hip ratio.

\section{Study Tools}

i. Predesigned, Pretested and Structured Schedule

ii. Measuring Tape

iii. Weighing Machine

iv. Modified B.G. Prasad scale for socioeconomic status, 2018

v. WHO’s BMI Chart for Adolescents 


\section{Study Variables}

i. Socio-demographic Variables such as age, religion, family income etc.

ii. Variables regarding Nutritional Status such as height, weight, waist-hip ratio etc.

\section{Study Procedure}

The topic was selected and placed before the Institutional Ethics Committee for obtaining necessary clearance. All adolescents who were permanent residents of the urban field practice area of our College formed the study population. Out of 25 slums, 3 were chosen randomly from which all adolescents outside the exclusion criteria, were included in the study following complete enumeration technique. The sample thus obtained was 291. After obtaining informed consent, they were interviewed and appropriate clinical examinations were done. Body weight was determined to the nearest $0.01 \mathrm{~kg}$ using a Tanita scale coupled to the BOD POD® Body Composition Tracking System (Life Measurement Instruments, Concord, California, USA) with subjects wearing underwear. Height was assessed without shoes to the nearest $0.5 \mathrm{~cm}$ by using a stadiometer (SECA, Modell 220, Hamburg, Germany). BMI was calculated as body weight (kg) / body height $(\mathrm{m})^{2}$. WC was measured with the subjects standing in upright position midway between the lowest rib and the top of the iliac crest. At the end of a normal expiration, the measurement was performed with a non- elastic plastic tape positioned parallel to the floor.

All data collected were entered in MS-Excel and analysed using SPSS version 21.

\section{Results}

The study population comprised of 123 (42.3\%) males and 168 (57.7\%) females (Table 1). Among them 198 (68\%) belonged to Hindu community and the rest 93 (32\%) were Muslims and most of them $162(55.7 \%)$ belong to nuclear family (Table 1). Mean age (year) for girls $(15.91 \pm 2.78)$ were slightly higher than the boys $(15.76 \pm 3.10)$. Majority of the population $(57.8 \%)$ were from middle class socio-economic status. Among the adolescents $6(2.06 \%)$ were found as school dropout. Anthropometric measurements revealed mean height, weight, waist circumference were more in boys than the girls (Table 2). According to BMI, among the study population $21(7.2 \%)$ were obese, 30 (10.3) were over-weight, 135 (46.4\%) were normal, 90 (30.9\%) were thin and 15 (5.2\%) were very thin (Figure 2). Gender, religion, education of parents, type of family and socioeconomic status were found significantly associated $(\mathrm{p}<0.05)$ with different categories of BMI (Table 1). Multinomial logistic regression found that gender, education of mother, type of family, socio-economic status, junk food consumption and regular physical exercise are significant predictors for thin to very thin BMI group whereas gender, religion, education of mother were the significant predictors for overweight to obese group (Table 3). Among the male adolescent significant $(\mathrm{p}<0.001)$ difference in waist circumference found in three BMI groups which is contributed by thin \& normal group $(p<0.001) \&$ thin and obese group $(p<0.001)$. For the female population waist circumference and waist-hip ratio were significantly different ( $<<0.001)$ among the three BMI groups (Table 4).

\section{Discussion}

The present urban community based crosssectional study among 291 adolescents including $123(42.3 \%)$ males and 168 (57.7\%) females was conducted to assess nutritional status and to correlate with socio-demographic-lifestyle factors. There are few references that are conducted in urban population, however study conducted by Ramachandra A et al. in an urban adolescent school population can be compared with the present study. The current study found that the mean weight and height for boys were more than the girls which is similar to the findings by Ramachandra et al. but unlike their study mean BMI was also more for boys. Overall prevalence of over-nutrition was $17.5 \%$ and under-nutrition was $36.1 \%$ and were significantly contributed by 
gender, religion, education of the parents and socio-economic status of the adolescents. More number of obese adolescents were found in upper socio-economic groups similar to Ramachandra et al. but no significant correlation was found with physical activity and food habits of the adolescents. Multi-linear logistic regression analysis revealed gender, education of the parents and socio-economic status as the significant contributor to adolescent malnutrition.

Table 1: Association of socio-demographic and lifestyle factors with Body Mass Index

\begin{tabular}{|c|c|c|c|c|c|c|}
\hline \multicolumn{2}{|l|}{ Factors } & \multicolumn{3}{|c|}{ BMI } & $x^{2}$ & $\mathrm{P}$ value \\
\hline Gender & Male $(n=123)$ & $\begin{array}{c}\begin{array}{c}\text { Thin to very } \\
\text { thin }\end{array} \\
60(48.8)\end{array}$ & $\begin{array}{l}\text { Normal } \\
36(29.3)\end{array}$ & $\begin{array}{c}\begin{array}{c}\text { Over weight to } \\
\text { obese }\end{array} \\
27(21.9)\end{array}$ & 26.37 & 0000 \\
\hline & Female $(n=168)$ & $45(26.8)$ & $99(58.9)$ & $24(29.4)$ & & \\
\hline \multirow{2}{*}{ Religion } & Hindu $(n=198)$ & $78(39.4)$ & $102(51.5)$ & $18(9.1)$ & \multirow[t]{2}{*}{30.54} & \multirow[t]{2}{*}{0.000} \\
\hline & Muslim (n=93) & $7(29.0)$ & $33(35.5)$ & $33(35.5)$ & & \\
\hline \multirow{2}{*}{$\begin{array}{l}\text { Education } \\
\text { of father }\end{array}$} & Up-to secondary $(\mathrm{n}=105)$ & $27(25.7)$ & $45(42.9)$ & $33(31.4)$ & \multirow[t]{2}{*}{23.45} & \multirow[t]{2}{*}{0.000} \\
\hline & Higher secondary or more $(n=186)$ & $78(41.9)$ & $90(48.4)$ & $18(9.7)$ & & \\
\hline \multirow{2}{*}{$\begin{array}{l}\text { Education } \\
\text { of mother }\end{array}$} & Up-to secondary $(n=132)$ & $27(20.5)$ & $45(42.9)$ & $33(31.4)$ & \multirow[t]{2}{*}{44.60} & \multirow[t]{2}{*}{0.000} \\
\hline & Higher secondary or more $(n=159)$ & $78(41.9)$ & $90(48.4)$ & $18(9.7)$ & & \\
\hline \multirow{2}{*}{$\begin{array}{l}\text { Type of } \\
\text { family }\end{array}$} & Joint $(n=129)$ & $54(41.9)$ & $60(46.5)$ & $15(11.6)$ & \multirow[t]{2}{*}{6.74} & \multirow[t]{2}{*}{0.034} \\
\hline & Nuclear $(n=162)$ & $51(31.5)$ & $75(46.3)$ & $36(22.2)$ & & \\
\hline \multirow{2}{*}{$\begin{array}{l}\text { Socio- } \\
\text { economic } \\
\text { status }\end{array}$} & Upper middle or more $(n=123)$ & $3(2.4)$ & $90(73.2)$ & $30(24.4)$ & \multirow[t]{2}{*}{105.49} & \multirow[t]{2}{*}{0.000} \\
\hline & Lower middle or less $(n=168)$ & $102(66.7)$ & $45(26.8)$ & $21(12.5)$ & & \\
\hline \multirow{2}{*}{$\begin{array}{l}\text { Consume } \\
\text { junk food }\end{array}$} & Yes $(n=249)$ & $87(34.9)$ & $117(47.0)$ & $45(18.1)$ & \multirow[t]{2}{*}{1.05} & \multirow[t]{2}{*}{0.591} \\
\hline & No $(n=42)$ & $18(42.9)$ & $18(42.9)$ & $6(14.3)$ & & \\
\hline \multirow{2}{*}{$\begin{array}{l}\text { Regular } \\
\text { Exercise }\end{array}$} & Yes $(n=198)$ & $78(39.4)$ & $84(42.4)$ & $36(18.2)$ & \multirow[t]{2}{*}{4.14} & \multirow[t]{2}{*}{0.126} \\
\hline & No $(n=93)$ & $27(29.0)$ & $51(54.8)$ & $15(16.2)$ & & \\
\hline
\end{tabular}

Table 2: Anthropometric measurements of the study population $(n=291)$

\begin{tabular}{|l|c|c|c|c|}
\hline \multirow{2}{*}{ Measurements } & \multicolumn{2}{|c|}{ Male $(\mathrm{n}=123)$} & \multicolumn{2}{c|}{ Female $(\mathrm{n}=168)$} \\
\cline { 2 - 5 } & Mean & SD & Mean & SD \\
\hline Height $(\mathrm{cm})$ & 159.24 & 14.36 & 151.46 & 8.09 \\
\hline Weight $(\mathrm{kg})$ & 55.49 & 16.13 & 47.18 & 12.05 \\
\hline Body Mass Index $\left(\mathrm{kg} / \mathrm{m}^{2}\right)$ & 21.53 & 4.64 & 20.32 & 3.98 \\
\hline Waist Circumference $(\mathrm{cm})$ & 72.21 & 14.94 & 70.69 & 11.65 \\
\hline Waist Hip Ratio & 0.86 & 0.12 & 0.84 & 0.08 \\
\hline
\end{tabular}

Table 3: Multinomial logistic regression analysis of socio-demographic and lifestyle factors associated with Body Mass Index $(\mathrm{n}=291)$

\begin{tabular}{|c|c|c|c|c|}
\hline BMI & \multicolumn{2}{|c|}{ Factors } & $P$ value & OR $(95 \% \mathrm{CI})$ \\
\hline \multirow[t]{16}{*}{ Thin to very thin } & \multirow[t]{2}{*}{ Gender } & Male & \multirow[t]{2}{*}{0.000} & \multirow[t]{2}{*}{$12.444(4.661-33.222)$} \\
\hline & & Female & & \\
\hline & \multirow[t]{2}{*}{ Religion } & Hindu & \multirow[t]{2}{*}{0.075} & \multirow[t]{2}{*}{$0.424(0.164-1.092)$} \\
\hline & & Muslim & & \\
\hline & \multirow[t]{2}{*}{ Education of father } & $\leq$ Secondary & \multirow[t]{2}{*}{0.40} & \multirow[t]{2}{*}{$0.602(0.184-1.965)$} \\
\hline & & $\geq$ Higher secondary & & \\
\hline & \multirow[t]{2}{*}{ Education of mother } & $\leq$ Secondary & \multirow[t]{2}{*}{0.014} & \multirow[t]{2}{*}{$0.240(0.077-0.750)$} \\
\hline & & $\geq$ Higher secondary & & \\
\hline & \multirow[t]{2}{*}{ Type of family } & Joint & \multirow[t]{2}{*}{0.047} & \multirow[t]{2}{*}{$2.251(1.010-5.015)$} \\
\hline & & Nuclear & & \\
\hline & \multirow[t]{2}{*}{ Socio-economic status } & $\geq$ Upper middle & \multirow[t]{2}{*}{0.000} & \multirow[t]{2}{*}{$0.004(0.001-0.016)$} \\
\hline & & $\leq$ Lower middle & & \\
\hline & \multirow[t]{2}{*}{ Consume junk food } & Yes & \multirow[t]{2}{*}{0.024} & \multirow[t]{2}{*}{$3.325(1.167-9.469)$} \\
\hline & & No & & \\
\hline & \multirow[t]{2}{*}{ Regular Exercise } & Yes & \multirow[t]{2}{*}{0.024} & \multirow[t]{2}{*}{$0.344(0.137-0.868)$} \\
\hline & & No & & \\
\hline \multirow[t]{2}{*}{ Over weight to obese } & \multirow[t]{2}{*}{ Gender } & Male & \multirow[t]{2}{*}{0.000} & \multirow[t]{2}{*}{$13.542(4.905-37.388)$} \\
\hline & & Female & & \\
\hline
\end{tabular}




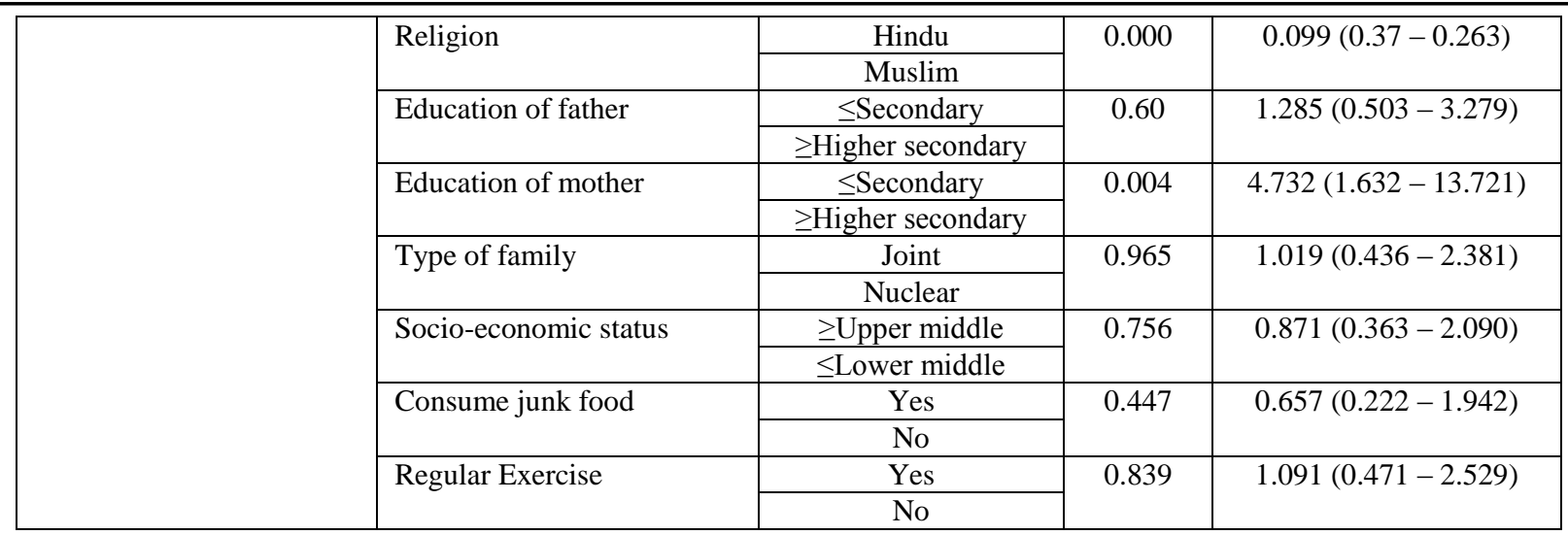

*Reference category is Normal BMI

Table 4: Sex-wise comparison of mean waist circumference and waist hip ratio among different BMI categories $(n=291)$

\begin{tabular}{|c|c|c|c|c|c|}
\hline \multirow[t]{2}{*}{ Gender } & \multirow[t]{2}{*}{ BMI Category } & \multicolumn{2}{|c|}{ Waist Circumference $(\mathrm{cm})$} & \multicolumn{2}{|c|}{ Waist - Hip Ratio } \\
\hline & & Mean \pm SD & ANOVA & Mean \pm SD & ANOVA \\
\hline \multirow[t]{3}{*}{ Male $(n=123)$} & $\begin{array}{l}\text { Thin to very } \\
\text { thin }(n=60)\end{array}$ & $77.85 \pm 16.81$ & \multirow[t]{3}{*}{$\begin{array}{c}\mathrm{F}(2,120)=9.72, \mathrm{p}= \\
0.000\end{array}$} & $0.86 \pm 0.15$ & \multirow[t]{3}{*}{$\begin{array}{c}\mathrm{F}(2,120)=0.098 \\
\mathrm{p}=0.907\end{array}$} \\
\hline & Normal $(n=36)$ & $66.0 \pm 10.38$ & & $0.87 \pm 0.05$ & \\
\hline & $\begin{array}{c}\text { Over weight to } \\
\text { obese }(n=27)\end{array}$ & $67.89 \pm 10.74$ & & $0.85 \pm 0.08$ & \\
\hline \multirow[t]{3}{*}{ Female $(n=168)$} & $\begin{array}{l}\text { Thin to very } \\
\text { thin }(n=45)\end{array}$ & $79.93 \pm 10.15$ & \multirow[t]{3}{*}{$\begin{array}{c}\mathrm{F}(2,165)=29.989 \\
\mathrm{p}=0.000\end{array}$} & $0.88 \pm 0.05$ & \multirow[t]{3}{*}{$\begin{array}{c}\mathrm{F}(2,165)=9.429 \\
\mathrm{p}=0.000\end{array}$} \\
\hline & Normal $(n=99)$ & $68.58 \pm 10.51$ & & $0.84 \pm 0.09$ & \\
\hline & $\begin{array}{c}\text { Over weight to } \\
\text { obese }(n=24)\end{array}$ & $62.13 \pm 7.44$ & & $0.79 \pm 0.08$ & \\
\hline
\end{tabular}

Figure 1: Distribution of study population according to socio-economic status $(n=291)$

\section{Socio-economic Status}

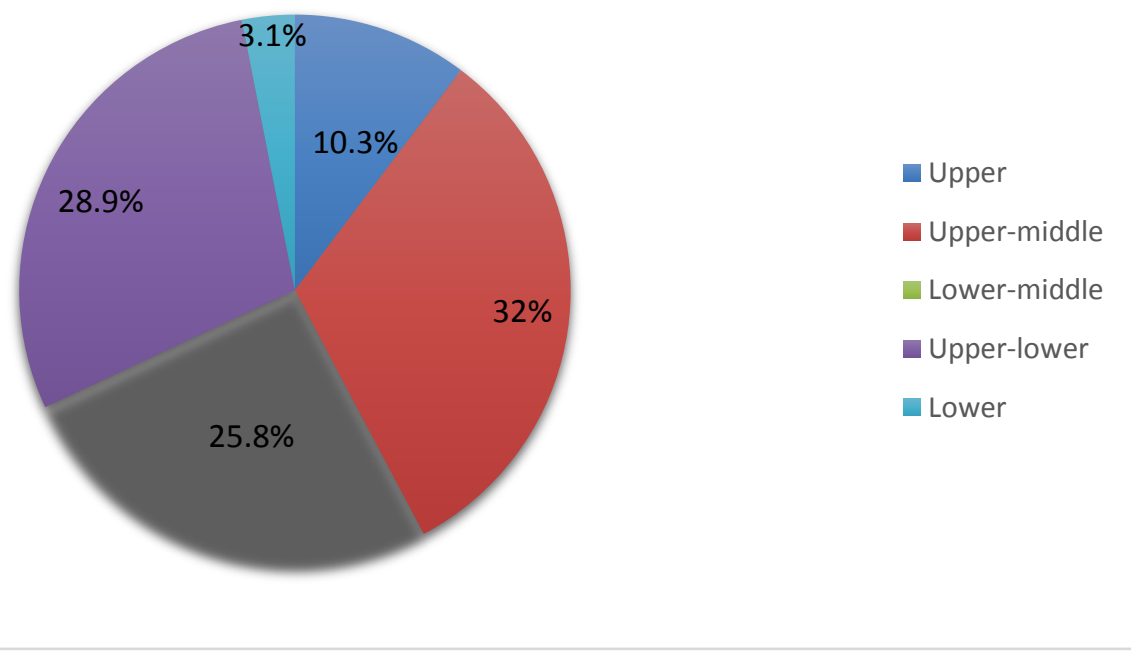


Figure 2: Distribution of study population according to BMI $(\mathrm{n}=291)$

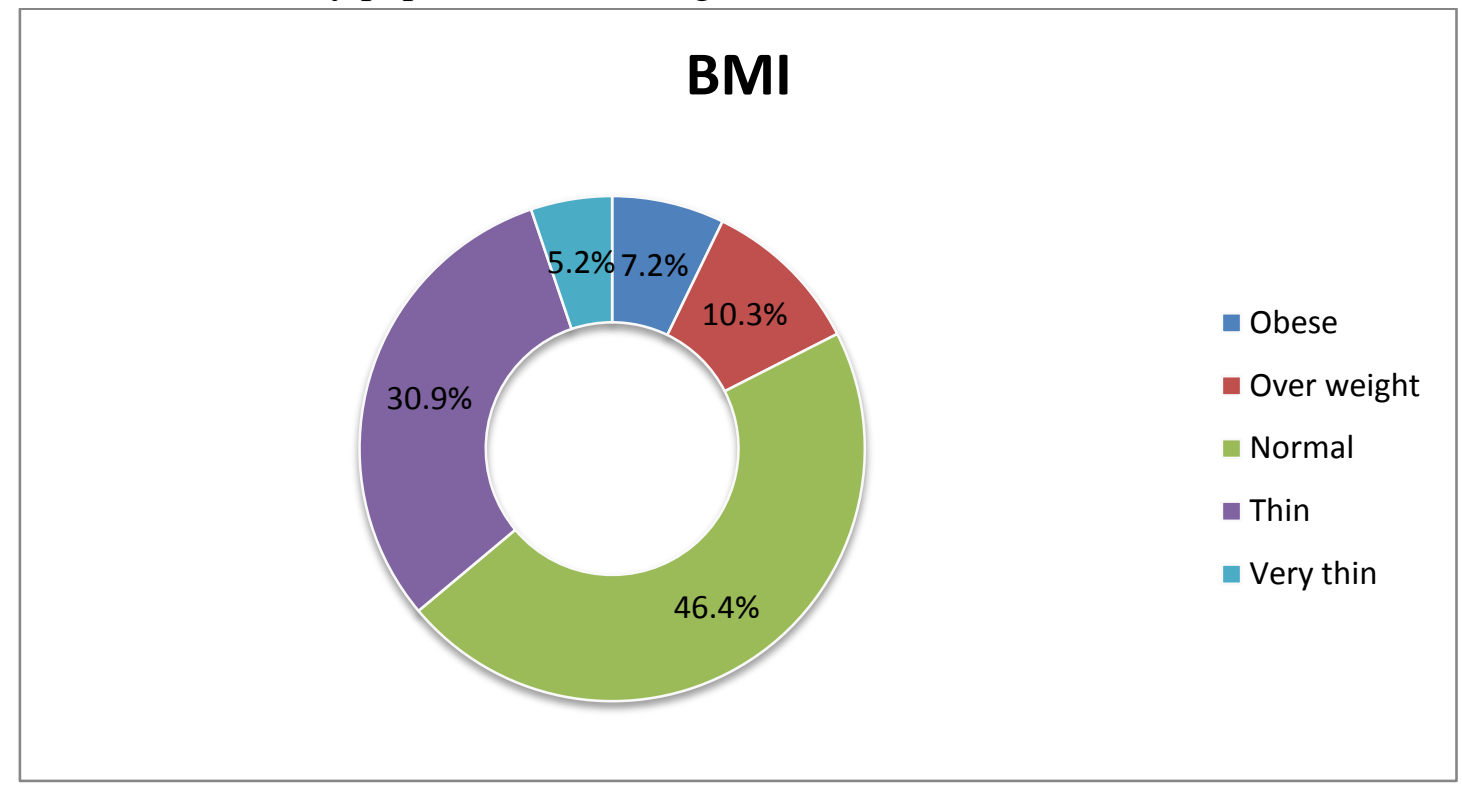

\section{Conclusion}

The study conducted in urban field practice area evaluated nutritional status of the adolescents in terms of both over-weight and thinness. Gender, parental education and socio-economic status are the contributing factors. Study with larger population and catering wider geographical area would have been more relevant. Strengthening adolescent health through adolescent health clinics will ameliorate their nutritional and other health related problems.

\section{Acknowledgement}

The authors sincerely thank the participants and the authorities for their support in conduction of the study.

\section{Grants availed: Self-funded}

\section{Conflicts of interest: None}

\section{References}

1. WHO. Maternal, newborn, child and adolescent health. Programmes and projects WHO Regional office for South East Asian. Available

at http://apps.searo.who.int/PDS_DOCS/B4771. pdf/ (last accessed on 9 April 2019).

2. Sawyer SM, Afifi RA, Bearinger LH, Blakemore SJ, Dick B, Ezeh AC.
Adolescence: a foundation for future health. The Lancet. 2012;379:1630-40.

3. Registrar General and Census Commissioner, India. Release of social and cultural tables age data highlights. Ministry of Home Affairs. Available at http://www.censusindia.gov.in/2011.../Census _2011_Age_data-final-12-09-2013

( last accessed on 3 February 2019 )

4. Tanner JM. Fetus into man. In: Tanner JM, eds. Physical Growth from Conception to Maturity. 1st ed. New York, Wells: Open Book Publishing Limited; 1978: 22-36.

5. RKSK Operational framework. Rashtriya Kishor Swasthya Karyakram. Adolescent health division Ministry of Health and Family Welfare Government of India. 2014. Available at http://nrhm.gov.in/images/pdf/programmes/R KSK/ RKSK_Operational_Framework.pdf ( last accessed on 6 February 2019)

6. WHO. Adolescent nutrition. A review of the situation in selected south-east Asian Countries. 2006. Available at URL:http://www.searo.who.int/LinkFiles/Nut rition__for_Health_and_Development_ Executive_Summary.pdf(Last accessed on 6 February 2019). 